\title{
Online Trust: The Influence of Perceived Company's Reputation on Consumers' Trust and the Effects of Trust on Intention for Online Transactions
}

\section{Andromachi Broutsou, Panos Fitsilis}

Project Management Department, TEI of Larissa, Larissa, Greece.

Email: fitsilis@teilar.gr

Received August $4^{\text {th }}, 2012$; revised September $13^{\text {th }}, 2012$; accepted September $23^{\text {rd }}, 2012$

\begin{abstract}
Trust is a basic ingredient in the creation, the evolvement and the conservation of a long-term relationship between suppliers and buyers. It is also a key differentiator in defining the success or failure of many e-business companies, in order to endorse the importance of online trust. In this paper we present a study on online trust in the $\mathrm{B} 2 \mathrm{C}$ context. More specifically, we focus on the issues of perceived company's reputation, online trust and intention for online transactions. The aim of this study is to examine if there is a positive relationship between perceived company's reputation and online trust, and between online trust and consumer's intention for online transactions.
\end{abstract}

Keywords: Online Trust; Perceived Company’s Reputation; Intention for Online Transactions

\section{Introduction}

In recent years electronic commerce is growing rapidly despite the dismal economy [1]. Also, e-commerce has highly contributed to the enhancing of economic growth, reduction of barriers of market entry, improvement of efficiency and effectiveness, reduction of costs and retention of lean inventories. Among customer's benefits of using the Internet are convenience, vast amounts of information, huge variety of products and services, and time savings [2]. Online shopping has a unique feature of uncertainty, anonymity, potential opportunism and lack of. On-line customers are required to share personal data (such as telephone number, e-mail address), financial information (such as credit card numbers), and face the risk of product and services not matching the website description or the risk of damage during the delivery process control [3]. In addition there seem to be little assurance of proper use of the personal information by the retailer [3]. According to Koufaris and Hampton-Sosa "Lack of trust in online companies is the primary reason why many web users do not shop online" [4].

Trust has been defined in different ways by various authors and is a multi-dimensional construct [5]. Trust is the "willingness to rely on another party and to take action in circumstances where such actions make one vulnerable to the other party" [6]. Trust is a basic ingredient in the creation, the evolvement and the conservation of a long-term relationship between suppliers and buyers. It also exists, when there is confidence, from the one party, for an exchange partner's credibility and integrity [6]. In the new business paradigm of online marketplaces, trust has been dealt with as a critical enabling factor for business-to-consumer (B2C) relationships [7] and to overcome many challenges. One of these challenges is how to build online trust to allay risks that associated with online transactions [1]. Perceived reputation influence user's trusting beliefs and trusting intentions towards a webbased vendor.

In turn, trusting beliefs, perceived web risk and trusting intention influence customer intentions to engage in the following behaviours:

- Share information with the vendor;

- Follow vendor advice; and

- Purchase from the web site [8].

The present study is going to focus on online trust since there the literature is limited in this subject. The purpose is to address the issues of perceived company's reputation, online trust and intention for online transactions. Therefore, the main objectives of the research are the following:

- To determine the extent to which the perceived reputation influence initial online trust as well as the ongoing online trust.

- To identify the importance of online trust on the consumers decision to buy through the web in the Greek cultural, behavioural, economical and demographical 
context.

- To determine the level of online trust and possible problems/issues emerge in the Greek context.

- To use the findings in order to make recommendations on the development of online trust in Greece.

The remaining of the paper is organised as follows: Section 2 presents the relevant literature, Section 3 presents the research methodology, while the results are presented in Section 4. The paper closes with the conclusions.

\section{Literature Review}

\subsection{Online Trust}

The importance of the nature of trust, its antecedents and consequents, is widely recognised. Sociologists, organisational behaviour scientists, psychologists, economists, political scientists and anthropologists have contributed to the wide body of knowledge which exists on this subject [9].

Similarly, online trust is of paramount importance since trust is crucial for the growth of e-commerce [10]. It is argued that "in the virtual world, the issue of trust gets magnified" and this highlights the significance of online trust [11]. F. S. Djahantighi and E. Fakar [12], stated that "online trust is one of the key obstacles to vendors succeeding on the internet medium. A lack of trust is likely to discourage online consumers from participating in e-commerce".

The lack of e-trust (online trust) is likely to deter any purchase over the internet [13]. E. Constantinides [14] supports that online trust is one of the factors that is frequently associated with the failure or success of online ventures and its multi-dimensional character makes it a complicated issue and he presents the most important trust elements which are: "Transaction Security", "Customer Data Abuse", "Customer Data Safety", "Uncertainty Reducing Elements" and "Guarantees Return Policies".

F. S. Djahantighi and E. Fakar [12] elaborated the factors that affect online trust and consequently consumer's intention to make an online purchase. These determinants of online trust are:

- Perceived Usefulness: It refers to the belief that a particular system would enhance effectiveness and job performance.

- Perceived Ease of Use: It is the belief that a particular system would be free from strenuous effort. Modern technology (Internet) enhances ease of use and triggers positive purchase behaviours, when making online transactions.

- Perceived Enjoyment of Technology: Useful and easily understood information on web sites lifts the de- gree of online trust, and influences positively purchase intention.

- Perceived Privacy and Security: Perceived privacy is the dissemination of information related to online transactions or behaviours.

- Company Competency: It includes issues such as company size, good reputation, willingness to customize and interactions with online customers.

\subsection{Company's Reputation}

When customers have no experience with a special evendor, reputation may be the key to absorb customers. From other people's word-of-mouth, customers can form positive experience towards the company. This can diminish the perception to risk and uncertainty online and help to increase customers to engender willingness to depend on the e-vendor [10]. In a study on online trust conducted by H. Y. Ha [15] was found that reputation is a critical component of trust.

Company's image and reputation have been often found to be crucial enablers of virtual interactions and transactions by decreasing the transaction risk as well as reducing consumer anxiety. High levels of brand awareness and good reputation reduces the online consumers' demands for integrity or credibility credentials [14]. According to M. Turilli et al. [16], "reputation is widely recognised as one of the main criteria used to assess the trustworthiness of a potential trustee. For this reason, an agent can trust another agent only by means of online interactions".

In online markets there is the opportunity to trade with a larger, fluctuating set of partners. But this means less reliance on long-term relationships. Many providers, such as eBay, Amazon, and Yahoo, in order to promote the exchange of information on the credibility of individual traders have instituted online reputation systems, known as "feed-back" systems, to provide the kind of word of mouth available in traditionally online markets. In fact, the advantage of online feedback systems over traditional word of mouth in that penetrating information online does not require personal contacts and in that feedback information from even large numbers of buyers can easily be collected and processed [17].

\subsection{Perceived Company's Reputation and Online Trust}

Y. H. Chen and S. Barnes in their paper tested the hypothesis "Perceived good reputation of the company is positively related to online initial trust in e-commerce" and found a positive correlation between them [18]. F. S. Djahantighi and E. Fakar [12] in their research paper tested the same hypothesis and contrary to the findings of 
Y. H. Chen and S. Barnes [18], found no correlation. The first research is conducted in the context of Taiwanese online bookstores and the second study was about Customer's Trends for Reservation Foreign Hotels via Internet.

The process of building a positive firm reputation is not easy to address since it is expensive and time-consuming and requires a great deal of consistent relationship-enhancing behaviour from the vendor's part towards its consumers. This process can be undermined very easily and any positive endeavour outweighed by a few mistakes by the firm. A company that acts in a consistent way concerning the creation of a positive reputation, especially when it has been established, has motive to continue doing this, and as people will consider reputation to be a credible variable upon which to assess trust in the company [4]. An individual tends to accept easily the generally opinion about the reputation of a company and to use it to form its own personal opinion regarding trust in that company. If several other people have the belief that a company has a certain degree of integrity, honesty and fairness, then a possible customer is likely to assume those qualities as well and use them to determine the extent to which can trust the company [4].

Consumer trust can increase significantly when a firm is perceived to have a good reputation. Perceived reputetion is "the degree in which people believe in the company's honesty and concern towards its customers" [4].

Many studies showed that there is a positive relationship between perceived reputation and online trust. S. L. Jarvenpaa and N. Tractinsky [10] in their research confirm that perceived reputation is positively related to online initial trust and to online on-going trust. D. H. McKnight et al. [8] found that perceived reputation had a positive impact on trusting beliefs in the company as well as on trusting intentions toward the company for new consumers. Perceived reputation is positively related to trust, especially initial trust, in the company [4]. Given that the literature provides stronger evidence for the positive relationship between perceived company's reputetion and online trust, the following hypothesis is proposed:

H1. There is a positive relationship between perceived company's reputation and online (initial and on-going) trust in the company.

\subsection{Virtual Customer Purchase Intention}

Understanding the mechanisms of online shopping and the behaviour of the virtual customer is a priority issue for practitioners competing in the fast expansion e-marketplace. This topic is also increasingly drawing the attention of researchers. Many online companies still do not understand completely the needs and behaviour of the online customer and continue to struggle with the issue of effective selling products online [14]. A good deal of research endeavour is focused on constructing models of online shopping and decision-making process. A new step which is fundamental in online buying has been added to the online shopping process: the step of building trust or confidence [14].

Pavlou [19] defines purchase intention "as the situation which manifests itself when a customer is willing and intends to become involved in online transactions".

From the online trust literature the most commonly identified consequences of trust are purchase intention and perceived risk. According to B. Ganguly et al., "purchase intention is concerned with the likelihood to purchase products online" [5]. Purchase intention is the last consistency of a number of cues for the e-commerce consumer. The more the vendor is capable of evoking the consumer's trust the more willing is the consumer to purchase from an online store [5]. Several studies [20,21] have shown that increase in consumer trust on the online seller increases purchase intention [5].

A number of studies have focused on the factors that influence customer decision making and behaviour in the environment of web-shopping. Some other findings are unique to the web environment. The web site layout design as well as the information content are significant in order to arouse initial customers' interest to further explore a web site [22]. In addition, matching channel characteristics and retail information disclose for customer shopping orientation is also significant factor. Perceived risk, perceived usefulness and ease of use, pervious adoption, perceived financial benefits and internet use would affect web-shopping adoption and also web-purchase intentions and decisions [22].

F. S. Djahantighi and E. Fakar (2010) [12] elaborated two factors affecting purchase intention for online transactions which are online trust and familiarity with online transactions. The existence of trust increases customers' beliefs that e-vendors will not participate in opportunistic behaviour. Besides, prior purchasing experiences are positively related to purchase intentions in e-commerce [18, 22].

According to C. M. Chiu et al. [23], the factors that are related to the purchase intention are perceived ease of use, perceived usefulness, website enjoyment and online trust.

\subsection{The Impact of Online Trust on Purchase Intention}

It has been demonstrated that online customers' purchase intention is positively affected by trusting beliefs $[8,9]$. Y. H. Chen and S. Barnes [19] stated that online initial trust has a positive impact on purchase intention. Trust would affect customer's intention to purchase a product from an online vendor. S. Grabner-Krauter and E. A. Kaluscha [3] 
agree that lack of trust is one of the most frequently mentioned reasons for customers not purchasing from online vendors. They also reported that trust in the e-commerce retailer influences customers' perceived risk of the transaction, the usefulness of the Web-site and perceived ease of use as well as the customers' intention to transact. Therefore, it is concluded, according to the above, that the level of trust and the intention for online transactions are positively related, and the following hypothesis is proposed:

H2. There is a positive relationship between the level of trust an individual has for an online business and the intention for online transactions.

\subsection{Online Trust and the Greek E-Commerce Context}

According to D. Maditinos and K. Theodoridis [24] there is low internet and technology infusion, as well as limited online market in Greece. According to N. K. Malhotra and J. D. McCort [25], important cultural differences between different countries extend to the e-commerce context. L. Chai and P. Pavlou [19] elaborated the case of cultural differences and other factors influence the electronic commerce adoption. They have endorsed that there is an important cultural dimension which is "uncertainty avoidance" and refers to how much people feel threatened by ambiguity. It is supported that Greece's score is the highest for any country measured [19]. Besides, L. Chai and P. Pavlou state that "this distinct cultural dimension is suggested to moderate consumers' intentions to adopt e-commerce". There is a moderating effect of uncertainty in the intention to purchase on-line. Since in Greece people feel importantly threatened by ambiguity, online trust is of high significance in the Greek context. "Countries with high uncertainty avoidance, such as Greece, dislike uncertain situations and prefer to act only under known conditions" [19]. A common mistake is to assume that all customer behaviour is similar. Managers of online shopping companies should modify their approaches, depending on the culture they are targeting [19]. When managers attempt to penetrate in the Greek market, they should focus on creating and fostering a safe online transactions image [19]. According to D. Maditinos and K. Theodoridis [24], the security perception is positively related to e-commerce customer satisfaction which is related to the intention of a consumer to repurchase through internet. Therefore it should be a priority to create a strong company's local identity and presence in the local country [19].

\section{Research Methodology}

Primary data for the research were collected by struc- tured questionnaire. The questionnaire included closeend questions, it counted on a five-point Likert scale from "1-Strongly Disagree" to "5-Strongly Agree" and it was based on the literature review. The sample consisted of users that are familiar with the Web and especially with the social networks (Facebook). Because the research took place in Greece, the questionnaire before uploading on Facebook, was translated in Greek with great attention so as not to lose the meaning of the questions. The questionnaire was anonymous and all the questions were based on previous research and theories after the study of several articles. In addition, the questions should be targeted in order to help in the research and to its better results. The distribution became online, uploading the questionnaire on Facebook in pages-groups and remained uploading for two weeks targeting in the participation of at least 200 users. Before the distribution of the questionnaire, was transacted a pretest in order to ascertain possible problems in the completion of the questionnaire as well to examine its structure and its understanding from the participants. The pretest involved 10 users.

The data were recorded electronically in a data base. The questions that use Likert scale analysed as quantitative (5-points scale). The aim was to investigate if the answers/attitudes (dependent variables) are affected by the demographics factors (independent variables). The quantitative methods (t-test and ANOVA test) were used in order to investigate if there are any differences in the answers/attitude between the categories of the categorical variables (demographics factors). For example, males and females. T-test is used when the categorical-independent variable has only two categories (i.e. the gender: male-female) while ANOVA is used when the categorical variable has more than three categories (i.e. educational level, age groups) [26].

For the statistical analysis of the data was used SPSS 15.0 software, because it is one of the most broadly used and reliable software.

In order to examine the reliability of the answers two couples of similar and two couples of contradictive questions had been created. Those who had more than two mistaken couples of questions were considered that had completed the questionnaire without particular attention and did not take part in the analysis. In this point it has to be mentioned that was not found any questionnaire with more than two mistaken couples of questions. Besides, users that had completed less than 50 per cent of the questions were rejected from the analysis because this kind of questionnaires did not give reliable answers and for this reason could not be examined the hypotheses of the research. 


\section{Discussion}

In order to explore the relation between perceived company's reputation and online trust, and between online trust and intention for online transaction, was used correlation analysis. Correlation analysis is a technique for investigating the relationship between two quantitative, continuous variables [26]. In order to test the relationship between these couples of variables was used Pearson's correlation coefficient ( $\mathrm{r}$ ).

Table 1 shows that the correlation between perceived company's reputation and online trust is $r=0.351$ and this implies that there is a moderate positive correlation. This denotes that an increase of perceived company's reputation involves an increase of online trust (score). As for the association between online trust and intention for online transactions, the correlation coefficient is equal to 0.225 . This degree expresses a low positive correlation between the two variables. This indicates that an increase of trust leads to a low increase of intention for online transactions. However, is worth mentioning that both of the values of coefficient correlation are statistically significant (both $\mathrm{P}$-value $<0.001$ ). This significance is due to high number of observations of the sample $(\mathrm{N}=206)$.

where Pearson correlation refers to the value of Pearson coefficient correlation, Sig.(2-tailed) refers to P-value and $\mathrm{N}$ is the number of observations.

Based on the values of Pearson correlation coefficient (r) was calculated the coefficient of determination $\left(\mathrm{R}^{2}\right.$ or $r$ square) as $R^{2}=r^{2}$. $R^{2}$ expresses the proportion of variance of the dependent variable $(\mathrm{Y})$ which is explained by the independent variable (X) [26].

According to the previous results, studying the $\mathrm{R}$ square between perceived company's reputation (independent variable) and online trust (dependent variable) it is concluded that $\mathrm{R}^{2}=0.123$. This denotes that $12.3 \%$ of the online trust variation is explained by the perceived company's reputation. About the $\mathrm{R}$ square between

Table 1. Correlations table.

\begin{tabular}{ccccc}
\hline & & Reputation & Trust & Intention \\
\hline \multirow{4}{*}{ Reputation } & Pearson Correlation & 1 & $0.351^{* *}$ & $0.306^{* *}$ \\
& Sig. (2-tailed) & & 0.000 & 0.000 \\
& $\mathrm{~N}$ & 206 & 206 & 206 \\
\multirow{5}{*}{ Trust } & Pearson Correlation & $0.351^{* *}$ & 1 & $0.225^{* *}$ \\
& Sig. (2-tailed) & 0.000 & & 0.001 \\
& $\mathrm{~N}$ & 206 & 206 & 206 \\
& Pearson Correlation & 1 & $0.351^{* *}$ & $0.306^{* *}$ \\
& Sig. (2-tailed) & & 0.000 & 0.000 \\
& $\mathrm{~N}$ & 206 & 206 & 206 \\
\hline
\end{tabular}

${ }^{* *}$ Correlation is significant at the 0.01 (2-tailed). online trust (independent variable) and intention for online transactions (dependent variable) it is concluded that $\mathrm{R}^{2}=0.051$. This indicates that online trust explains 5.1\% of the intention for online transactions variability.

Multivariate statistical analysis was applied to explore the research hypotheses and to assess the influence of other (independent) variables on the dependent variables. Variables taking into account, also, the demographic characteristics. Regression analysis is used either to predict the value of a quantitative dependent variable, based on the value of at least one independent variable and to explain the impact of changes in an independent variable on the dependent variable or to find out which factors (independent variables) and how these factors effect on the dependent variable [26]. In this study, multiple linear regression analysis was performed using the stepwise method in order to test the research hypotheses taking into account, also, the demographic characteristics.

\subsection{Regression Analysis between Online Trust and Perceived Company's Reputation}

The execution of the multiple linear regression model in which the demographic characteristics were included as well, were created the results below. In this model trust was considered as dependent variable while perceived company's reputation as a predictor (independent variable). Looking at the Table 2, specifically in model 2 (final model), the coefficient of perceived company's reputation $\beta$ is equal to 0.381 ( $\mathrm{P}$-value $<0.001<0.05$ ) and of Age Dummy2, $\beta$ is equal to -0.323 ( $\mathrm{P}$-value $=$ $0.007<0.05)$. Both of these predictors are statistically significant for online trust. This means that these variables have an impact on the levels of online trust.

Specifically, increasing the perceived company's reputation score by one, online trust's score is increased by 0.381 having the rest factors stable. About Age_Dummy2, the coefficient $\beta=-0.323$ indicates that online trust decreases significantly more in people who are older than 35 years (by 0.323) compared to those who are $17-24$ years old. Therefore, it is concluded that there is a positive relationship between perceived company's reputation and online trust and a negative relationship between age and online trust.

ANOVA table (Table 3) denotes that our model (model 2) is overall statistically significant as it has a P-value $<0.001$.

From Table 4 (model 2), it can be seen that $\mathrm{R}^{2}$ adjusted $=$ 0.145 . This implies that our regression model presents $14.5 \%$ of online trust variation. Therefore, these explanatory variables can explain a small part of online trust. Based on the above findings, Hypothesis 1 is supported as presented in Table 4. 
Table 2. Regression coefficients for perceived company's reputation and online trust.

\begin{tabular}{|c|c|c|c|c|c|c|c|c|}
\hline & \multirow{2}{*}{ Model } & \multicolumn{2}{|c|}{$\begin{array}{l}\text { Unstandardized } \\
\text { Coefficients }\end{array}$} & \multirow{2}{*}{$\begin{array}{c}\begin{array}{c}\text { Standardized } \\
\text { Coefficients }\end{array} \\
\text { Beta }\end{array}$} & \multirow[t]{2}{*}{$\mathrm{T}$} & \multirow[t]{2}{*}{ Sig. } & \multicolumn{2}{|c|}{$95 \%$ Confidence Interval for B } \\
\hline & & B & Std. Error & & & & Lower Bound & Upper Bound \\
\hline \multirow{2}{*}{1} & (Constant) & 2.676 & 0.223 & & 11.998 & 0.000 & 2.236 & 3.115 \\
\hline & Reputation & 0.351 & 0.066 & 3.51 & 5.336 & 0.000 & 0.221 & 0.481 \\
\hline \multirow{3}{*}{2} & (Constant) & 2.645 & 0.220 & & 12.031 & 0.000 & 2.212 & 3.079 \\
\hline & Reputation & 0.381 & 0.066 & 0.380 & 5.794 & 0.000 & 0.251 & 0.510 \\
\hline & Age_Dummy2 & -0.323 & 0.119 & -0.178 & -2.710 & 0.007 & -0.558 & -0.088 \\
\hline
\end{tabular}

a. Dependent variable:Trust where $B($ or $\beta)$ is the value of coefficient, $t$ is the value of t-test and Sig.: represents the P-value.

Table 3. ANOVA for perceived company's reputation and online trust.

\begin{tabular}{ccccccc}
\hline \multirow{2}{*}{ Model } & $\begin{array}{c}\text { Sum of } \\
\text { Squares }\end{array}$ & df & Mean Square & F & Sig. \\
\hline \multirow{1}{*}{1} & Regression & 13.789 & 1 & 13.789 & & \\
& Residual & 98.298 & 203 & 0.484 & 28.477 & $0.000^{\mathrm{a}}$ \\
& Total & 112.088 & 204 & & & \\
& Regression & 17.237 & 2 & & & \\
2 & Residual & 94.851 & 202 & 8.618 & & \\
& Total & 112.088 & 204 & 0.470 & 18.354 & $0.000^{\mathrm{b}}$ \\
& & & & & \\
\hline
\end{tabular}

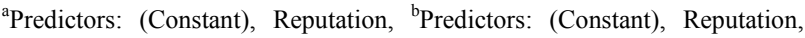
Age_Dummy2.

Table 4. Model summary.

\begin{tabular}{ccccc}
\hline Model & R & R Square & $\begin{array}{c}\text { Adjusted R } \\
\text { Square }\end{array}$ & $\begin{array}{c}\text { Std. Error of the } \\
\text { Estimate }\end{array}$ \\
\hline 1 & $0.351^{\mathrm{a}}$ & 0.123 & 0.119 & 0.6959 \\
2 & $0.392^{\mathrm{b}}$ & 0.154 & 0.145 & 0.6852 \\
\hline
\end{tabular}

a Predictors: (Constant), Reputation, ${ }^{\mathrm{b}}$ Predictors: (Constant), Reputation, Age_Dummy2.

\subsection{Regression Analysis between Intention for Online Transactions and Online Trust}

In this section analysis of the intention for online transactions was considered as dependent variable and online trust as explanatory variable. Conducting a multiple linear regression analysis in which the demographic variables were inserted in the model as well, resulting in a regression model (model 4 in Table 5) in which are included the predictors online trust $(\beta=0.225, \mathrm{P}$-value $=$ $0.001<0.05)$, Prof_Dummy2 $(\beta=0.701$, P-value $<$ $0.001<0.05)$, Educ_Dummy2 $(\beta=0.347$, P-value $=0.006$ $<0.05)$ and Prof_Dummy1 $(\beta=0.528$, P-value $=0.007<$ $0.05)$ are statistically significant factors for intention for online transactions. Looking at their P-values it is concluded that all of these variables are statistically significant factors for intention for online transactions.
Interpreting the results below someone can say that increasing the online trust by one then intention for online transactions is increased by 0.225 having the rest factors stable. About Prof_Dummy2, this denotes that employed people have increased intention for online transactions compared to unemployed people. The conclusion is the same when you compare students to unemployed people. Still, from the education dummy variable (Educ_Dummy2) it is concluded that people who have acquired master or $\mathrm{PhD}$ have increased intention for online transactions compared to those that have graduated from senior high school.

Below, ANOVA Table 6 presents that the model (model 4) is overall statistically significant as it has a P-value $<0.001$.

Finally, examining the proportion of intention for online transactions variance, which is interpreted in Table 7 (model 4), by looking at $\mathrm{R}_{\text {adjusted }}$ it can be seen that this model explains $13.4 \%$ of intention for online transactions variability. Therefore, these explanatory variables can explain a small part of intention for online transactions. Based on the above findings, Hypothesis 2 is supported.

\section{Conclusions}

Perceived company's reputation, online trust and intention for online transactions are three of the issues for which a large number of researchers are working on these in the academic community. Trust is very essential and has been called key to e-commerce and therefore building trust is even more vital.

The contribution of this paper, concerns the study of the relationship between perceived company's reputation and online trust and between online trust and intention for online transactions according to the beliefs and opinions of the sample. These conclusions can contribute greatly in understanding consumer behaviour for e-commerce services and therefore to help improving the offered services. 

on Intention for Online Transactions

Table 5. Regression Coefficient for online trust and intention for online transactions.

\begin{tabular}{|c|c|c|c|c|c|c|c|c|}
\hline & \multirow{2}{*}{ Model } & \multicolumn{2}{|c|}{$\begin{array}{l}\text { Unstandardized } \\
\text { Coefficients }\end{array}$} & \multirow{2}{*}{$\begin{array}{c}\begin{array}{c}\text { Standardized } \\
\text { Coefficients }\end{array} \\
\text { Beta }\end{array}$} & \multirow{2}{*}{$\mathrm{T}$} & \multirow{2}{*}{ Sig. } & \multicolumn{2}{|c|}{$95 \%$ Confidence Interval for B } \\
\hline & & B & Std. Error & & & & Lower Bound & Upper Bound \\
\hline \multirow{2}{*}{1} & (Constant) & 2.479 & 0.280 & & 8.851 & 0.000 & 1.927 & 3.031 \\
\hline & Trust & 0.240 & 0.072 & 0.229 & 3.354 & 0.001 & 0.099 & 0.382 \\
\hline \multirow{3}{*}{2} & (Constant) & 2.280 & 0.283 & & 8.067 & 0.000 & 1.723 & 2.837 \\
\hline & Trust & 0.239 & 0.070 & 0.228 & 3.404 & 0.001 & 0.101 & 0.378 \\
\hline & Prof_Dummy2 & 0.322 & 0.108 & 0.201 & 2.993 & 0.003 & 0.110 & 0.534 \\
\hline \multirow{4}{*}{3} & (Constant) & 2.250 & 0.279 & & 8.053 & 0.000 & 1.699 & 2.802 \\
\hline & Trust & 0.232 & 0.070 & 0.221 & 3.342 & 0.001 & 0.095 & 0.369 \\
\hline & Prof_Dummy2 & 0.307 & 0.106 & 0.191 & 2.886 & 0.004 & 0.097 & 0.517 \\
\hline & Educ_Dummy2 & 0.308 & 0.125 & 0.163 & 2.454 & 0.015 & 0.060 & 0.555 \\
\hline \multirow{4}{*}{4} & Trust & 0.225 & 0.068 & 0.225 & 3.289 & 0.001 & 0.090 & 0.360 \\
\hline & Prof_Dummy2 & 0.701 & 0.178 & 0.437 & 3.935 & 0.000 & 0.350 & 1.053 \\
\hline & Educ_Dummy2 & 0.347 & 0.124 & 0.183 & 2.790 & 0.006 & 0.102 & 0.592 \\
\hline & Prof_Dummy1 & 0.528 & 0.193 & 0.305 & 2.733 & 0.007 & 0.147 & 0.909 \\
\hline
\end{tabular}

${ }^{\mathrm{a}}$ Dependent Variable: Intention.

Table 6. ANOVA for online trust and intention for online transactions.

\begin{tabular}{|c|c|c|c|c|c|c|}
\hline & Model & $\begin{array}{l}\text { Sum of } \\
\text { Squares }\end{array}$ & df & $\begin{array}{c}\text { Mean } \\
\text { Square }\end{array}$ & $\mathrm{F}$ & Sig. \\
\hline \multirow{3}{*}{1} & Regression & 6.477 & 1 & \multirow{3}{*}{$\begin{array}{l}6.477 \\
0.576\end{array}$} & \multirow{3}{*}{11.249} & \multirow{3}{*}{$0.001^{\mathrm{a}}$} \\
\hline & Residual & 116.895 & 203 & & & \\
\hline & Total & 123.372 & 204 & & & \\
\hline \multirow{3}{*}{2} & Regression & 11.440 & 2 & \multirow{3}{*}{$\begin{array}{l}5.720 \\
0.554\end{array}$} & \multirow{3}{*}{10.328} & \multirow{3}{*}{$0.000^{b}$} \\
\hline & Residual & 111.932 & 202 & & & \\
\hline & Total & 123.372 & 204 & & & \\
\hline \multirow{3}{*}{3} & Regression & 14.697 & 3 & \multirow{3}{*}{$\begin{array}{l}4.899 \\
0.541\end{array}$} & \multirow{3}{*}{9.061} & \multirow{3}{*}{$0.000^{\mathrm{c}}$} \\
\hline & Residual & 108.676 & 201 & & & \\
\hline & Total & 123.372 & 204 & & & \\
\hline \multirow{3}{*}{4} & Regression & 18.610 & 4 & \multirow{3}{*}{$\begin{array}{l}4.652 \\
0.524\end{array}$} & \multirow{3}{*}{8.882} & \multirow{3}{*}{$0.000^{\mathrm{d}}$} \\
\hline & Residual & 104.762 & 200 & & & \\
\hline & Total & 123.372 & 204 & & & \\
\hline
\end{tabular}

${ }^{a}$ Predictors: (Constant), Trust; ${ }^{b}$ Predictors: (Constant), Trust, Prof Dummy2; ${ }^{\mathrm{c}}$ Predictors: (Constant), Trust, Prof_Dummy2, Educ_Dummy2; ${ }^{\mathrm{T}}$ Predictors: (Constant), Trust, Prof_Dummy2, Educ_Dummy2, Prof_Dummy1.

Table 7. Model summary.

\begin{tabular}{ccccc}
\hline Model & R & R Square & $\begin{array}{c}\text { Adjusted R } \\
\text { Square }\end{array}$ & $\begin{array}{c}\text { Std. Error of } \\
\text { the Estimate }\end{array}$ \\
\hline 1 & $0.229^{\mathrm{a}}$ & 0.053 & 0.048 & 0.7588 \\
2 & $0.305^{\mathrm{b}}$ & 0.093 & 0.084 & 0.7444 \\
3 & $0.345^{\mathrm{c}}$ & 0.119 & 0.106 & 0.7353 \\
4 & $0.388^{\mathrm{d}}$ & 0.151 & 0.134 & 0.7237 \\
\hline
\end{tabular}

a Predictors: (Constant), Trust; ${ }^{b}$ Predictors: (Constant), Trust, Prof Dummy2; ${ }^{\mathrm{c}}$ Predictors: (Constant), Trust, Prof_Dummy2, Educ_Dummy2; ${ }^{\mathrm{d}}$ Predictors: (Constant), Trust, Prof_Dummy2, Educ_Dummy2, Prof_Dummy1.
However, this study has a number of limitations such as: the customer sample was taken from Greece and therefore that study cannot describe consumer behaviour in a global market, and since the used questionnaire was distributed through Facebook it excludes all those that are not Facebook members.

\section{REFERENCES}

[1] X. Hu, G. Wu, Y. Wu and H. Zhang, "The Effects of Web Assurance Seals on Consumers' Initial Trust in an Online Vendor: A Functional Perspective," Decision Support Systems, Vol. 48, No. 2, 2010, pp. 407-418. doi:10.1016/j.dss.2009.10.004

[2] C. Liu, J. T. Marchewka, J. Lu and C. S. Yu, "Beyond Concern: A Privacy-Trust-Behavioral Intention Model of Electronic Commerce," Information \& Management, Vol. 42, No. 1, 2004, pp. 89-304. doi:10.1016/j.im.2004.01.002

[3] S. Grabner-Krauter and E. A. Kaluscha, "Empirical Research in On-Line Trust: A Review and Critical Assessment," International Journal of Human-Computer Studies, Vol. 58, No. 6, 2003, pp. 783-812. doi:10.1016/S1071-5819(03)00043-0

[4] M. Koufaris and W. Hampton-Sosa, "The Development of Initial Trust in an Online Company by New Customers," Information \& Management, Vol. 41, No. 3, 2004, pp. 377-397.

[5] B. Ganguly, S. B. Dash, D. Cyr and M. Head, "The Effects of Website Design on Purchase Intention in Online Shopping: The Mediating Role of Trust and the Moderating Role of Culture," International Journal of Electronic Business, Vol. 8, No. 4-5, 2010, pp. 302-330. doi:10.1504/IJEB.2010.035289 
[6] L. F. Lages, A. Lancastrea and C. Lages, "The B2B-RELPERF Scale and Scorecard: Bringing Relationship Marketing Theory into Business-to-Business Practice," Industrial Marketing Management, Vol. 37, No. 6, 2008, pp. 686-697. doi:10.1016/j.indmarman.2007.05.008

[7] C. L. Kun, K. Inwon and D. H. McKnight, "Transfer from Offline Trust to Key Online Perceptions: An Empirical Study," IEEE Transactions on Engineering Management, Vol. 54, No. 4, 2007, pp. 729-741. doi:10.1109/TEM.2007.906851

[8] D. H. McKnight, V. Choudhury and C. Kacmar, "The Impact of Initial Consumer Trust on Intentions to Transact with a Web Site: A Trust Building Model," Journal of Strategic Information Systems, Vol. 11, No. 3-4, 2002, pp. 297-323. doi:10.1016/S0963-8687(02)00020-3

[9] R. Connolly and F. Bannister, "Factors Influencing Irish Consumers' Trust," Management Research News, Vol. 31, No. 5, 2008, pp. 339-358. doi:10.1108/01409170810865154

[10] H. Wang and $\mathrm{Z}$. Hu, "Online Trust between Inexperienced Consumers and Experienced Consumers: An Empirical Study," Second International Conference on Future Information Technology and Management Engineering, Hong Kong, 13-14 November 2009, pp. 167-170. doi:10.1109/FITME.2009.47

[11] P. Durkan, M. Durkin and J. Gillen, "Exploring Efforts to Engender On-Line Trust," International Journal of Entrepreneurial Behaviour \& Research, Vol. 9, No. 3, 2003, pp. 93-110. doi:10.1108/13552550310476184

[12] F. S. Djahantighi and E. Fakar, "Factors Affecting Customer's Trends for Reservation Foreign Hotels via Internet in Iran," International Bulletin of Business Administration, No. 7, 2010, pp. 6-14. http://www.eurojournals.com/IBBA_7.htm

[13] B. Merrilees and M. L. Fry, "E-Trust: The Influence of Perceived Interactivity on E-Retailing Users," Marketing Intelligence and planning, Vol. 21, No. 2, 2003, pp. 123128. doi: $10.1108 / 02634500310465461$

[14] E. Constantinides, "Influencing the Online Consumer'S Behavior: The Web Experience," Internet Research, Vol. 14, No. 2, 2004, pp. 111-126. doi:10.1108/10662240410530835

[15] H. Y. Ha, "Factors Influencing Consumer Perceptions of Brand Trust Online," Journal of Product \& Brand Management, Vol. 13, No. 5, 2004, pp. 329-342.

\section{doi:10.1108/10610420410554412}

[16] M. Turilli, A. Vaccaro and M. Taddeo, "The Case of Online Trust," Knowledge, Technology and Policy, Vol. 23, No. 3-4, 2010, pp. 333-345.

[17] G. Bolton, E. Katok and A. Ockenfels, "How Effective Are Electronic Reputation Mechanisms? An Experimental Investigation," Management Science, Vol. 50, No. 11, 2004, pp. 1587-1602. doi:10.1287/mnsc. 1030.0199

[18] Y. H. Chen and S. Barnes, "Initial Trust and Online Buyer Behaviour," Industrial Management \& Data Systems, Vol. 107, No. 1, 2007, pp. 21-36. doi: $10.1108 / 02635570710719034$

[19] L. Chai and P. Pavlou, "From 'Ancient' to 'Modern': A Cross-Cultural Investigation of Electronic Commerce Adoption in Greece and the United States," The Journal of Enterprise Information Management, Vol. 17, No. 6, 2004, pp. 416-423. doi:10.1108/17410390410566706

[20] F. Sultan and H. A. Mooraj, "Designing a Trust-Based E-Business Strategy," Marketing Management, American Marketing Association, 2001, pp. 40-45.

[21] E. Y. Kim and Y. K. Kim, "Predicting Online Purchase Intentions for Clothing Products," European Journal of Marketing, Vol. 38, No. 7, 2004, pp. 883-897. doi:10.1108/03090560410539302

[22] W. C. M. So, T. N. D. Wong and D. Sculli, "Factors Affecting Intentions to Purchase via the Internet," Industrial Management and Data Systems, Vol. 105, No. 9, 2005, pp. 1225-1244. doi:10.1108/02635570510633275

[23] C. M. Chiu, C. C. Chang, H. L. Cheng and Y. H. Fang, "Determinants of Customer Repurchase Intention in Online Shopping," Online Information Review, Vol. 33, No. 4, 2009, pp. 761-784. doi:10.1108/14684520910985710

[24] D. Maditinos and K. Theodoridis, "Satisfaction Determinants in the Greek Online Shopping Context," Information Technology \& People, Vol. 23, No. 4, 2010, pp. 312329. doi:10.1108/09593841011087789

[25] N. K. Malhotra and J. D. McCort, "A Cross-Cultural Comparison of Behavioral Intention Models Theoretical Consideration and an Empirical Investigation," International Marketing Review, Vol. 18, No. 3, 2001, pp. 235-269. doi:10.1108/02651330110396505

[26] A. P. Field, "Discovering Statistics Using SPSS (and Sex and Drugs and Rock 'n' Roll)," 2nd Edition, Sage, London, 2005. 